\title{
Usefulness of hydrographic and sozological databases in ecological studies of rivers in Poland
}

\author{
Renata Graf, Leszek Sobkowiak \\ Adam Mickiewicz University, Faculty of Geographical and Geological Sciences, \\ Institute of Physical Geography and Environmental Planning, Department of Hydrology and Water Management, \\ Dzięgielowa 27 str., 61-680 Poznań, Poland \\ e-mail: rengraf@amu.edu.pl,
}

\begin{abstract}
An assessment of ecological conditions of streams and other water bodies is one of the requirements of the Water Framework Directive No. 2000/60/EC. The paper deals with the potential use of hydrographic and sozological databases and thematic maps at a scale of 1:50,000 (Hydrographic Map, Sozological Map) compiled on their basis at selected stages of eco-hydrological evaluation of streams, especially at the stage of collecting information on water bodies. Attention was paid to the possible use of that data in identification of sections of river valley estimated from the point of view of its components, i.e. under protection, and determining the level of urbanization of the valley, location of municipal investments, infrastructure and hydraulic structures, which are the measures of the man-made transformation of the valley. An assessment of the ecological state and potential of surface waters is the basis of eco-hydrological studies and the fundamental requirement of the Water Framework Directive, thus is the starting-point for river system valorisation.
\end{abstract}

Key words: hydrographic database, sozological database, eco-hydrological studies, river, Geographical Information Systems.

\section{Introduction}

The Geographical Information Systems (GIS) are created at different spatial levels: global, continental, regional and local (Bonham-Carter 1994; Store \& Jokimaki 2003; DeMers2005; EEA 2005; Longley 2005; Berry 2006; Wang 2006). There are two systems: the Global Earth Observation System of Systems and the Global Monitoring for Environment and Security, which play roles of global systems collecting data on the Earth, including hydrological data, and aiming to integrate the satellite, marine and terrestrial (surface) data (GEOSS, GMES). That information is used in cartographic and database projections as well as in water resources management, including water-crisis management and prognoses of hydrological phenomena.

The Infrastructure for Spatial Information (INSPIRE) in the European Union (EU) aims to gather, store and facilitate spatial data, compile data originating from differ- ent European sources as well as assess their usefulness for specific purposes. One of the environmental goals realized by the EU countries within the Guidelines to the Water Framework Directive No. 2000/60/EC (2000) is an assessment of ecological state of surface and underground waters, which allows taking appropriate measures to protect water resources.

Poland, as a member of the EU is also engaged in the development of the INSPIRE system through so-called National Spatial Data Infrastructure (NSDI), which includes topographical maps (civil and military), thematic maps (hydrographic, sozological, geological, etc.), independent digital databases (the All-Geographical Database, the Computer Map of Hydrographic Division of Poland), geodesy databases and photogrammetric compilations. These systems and spatial databases comprise data and metadata, which are defined by the guidelines of the INSPIRE Directive. 
The State Geographical Information System in Poland has been created at three spatial levels: national, provincial (voivodeship) and district. Among them, the provincial level is based on the Topographical Database (digital database, ortophotomap, digital terrain model) at a scale of 1:10,000 and VMap L2 at a scale of 1:50,000 constituting reference material for thematic maps: hydrographic and sozological (Graf et al. 2005; The GIS Technical Guidelines-3 2005; The GIS Technical Guidelines-4 2005; Graf \& Olszewski 2006; Graf 2009; Olszewski et al. 2009, 2010).

\section{Objectives and outline of the content}

Effective management and protection of water resources is connected with an assessment of their quantitative and qualitative state, which are shaped by both natural factors and human activity. Depending on the type of influence and degree of vulnerability of the natural environment to anthropogenic pressure, different degrees of modification of water conditions on a given area can be observed (Huggenberger et al. 1998; Speth, 2000; UNDP 2000; Zalewski 2000; UNEP 2002; Zalewski 2002; Brooks et al. 2005; Adger 2006; Smit \& Wandel 2006). This requires constant gathering of information and updating databases. Advancing urban development of catchments, mostly river valleys, results in transformation of the structure and conditions of functioning of river systems. An increasing role of an anthropogenic factor in shaping the natural environment leads to frequent outdating information on its components. In that case, obtaining and collecting suitable thematic data as well as the possibility of its updating and integration with geographical information systems is of key importance.

An assessment of the state and tendencies of transformation of the environment of river valleys and river channels is one of main problems in eco-hydrological studies (Gordon et al. 1992; Janauer 2000; Thoms 2003; Thoms et al. 2005; Dollar et al. 2007; Harper et al. 2008; James et al. 2010; Kennard et al. 2010). It also constitutes a basis for achieving an environmental goal defined in the Guidelines to the Water Framework Directive No. 2000/60/EC (2000) which refers to forecasting actions related to protection and re-naturalization of river systems. In this situation, thematic hydrographic and sozological databases, together with maps created on their foundations, can be useful as a source of information. These databases and maps can be used at the stage of both identification and valorisation of the river system characteristics as well as preparation of plans of water resources management in a catchment.

High complexity is one of the properties of river systems. This fact gives rise to a necessity of description and identification of the river system characteristics with the help of many topographic and thematic data. According to Gutry-Korycka (1999), an interdisciplinary approach is able to determine an optimal use of different methods for defining the extent of hydrological, morphological, biological and chemical variables that modify properties of a river ecosystem. An assessment of the ecological state and potential of surface waters, as the basis of eco-hydrological studies and the fundamental requirement of the Water Framework Directive, is the starting-point for river system valorisation.

With reference to the above-mentioned assumptions the possible use of hydrographic and sozological databases and thematic maps created on their base at a scale of 1:50,000 the Hydrographic Map of Poland and the Sozological Map of Poland, has been discussed at selected stages of river valorisation, especially at the stage of collecting information on water bodies. The assessment of the usefulness of selected databases in eco-hydrological studies on river systems has been made at the following phases:

1. analysis of source materials - realized thematic databases;

2. selection of thematic databases - criteria of selection;

3 . analysis of information levels of hydrographic and sozological databases;

4. assessment of the usefulness of selected databases in identification of river system characteristics - selection of thematic layers and their compilation;

5. definition of the weight of selected thematic databases at the stage of valorisation of the ecological state of the river system:

- a concept of creation of digital database related to selected group of parameters (for example: hydrological, morphological) of the river system as the starting-point for the "piece-by-piece" valorisation of the river system;

- a concept of creation of complex digital database, integrating both biotic and abiotic elements of the water ecosystem as the starting-point for valorisation of its ecological state;

6. visualization of information in an optional layout of the database thematic layers.

Special attention has been paid to the possible use of information obtained from the hydrological and sozological databases in inventorying hydrological and morphological elements of streams as well as - to a smaller extent - physico-chemical characteristics of river ecosystems. Acquired sets of data can be used in an assessment of relations between elements of the given river system and other components of the natural environment.

\section{Eco-hydrological studies of river systems and their main assumptions}

Specific character of the river system not only results from its complex structure, but is also connected with the role 
Table 1. Categories of parameters applied in the evaluation of the ecological status of river systems

\begin{tabular}{|c|c|c|}
\hline & Methods of eco-morphological valorisation & Guidelines to the Water Framework Directive \\
\hline Information level & $\begin{array}{l}\text { Groups of parameters } \\
\text { Most frequently used parameters } \\
\text { (by Ilnicki \& Lewandowski 1997) }\end{array}$ & $\begin{array}{l}\text { Thematic blocks } \\
\text { Obligatory \& optional parameters } \\
\text { (according to the WFD No. 2000/60/EC) }\end{array}$ \\
\hline RIVER BASIN & $\begin{array}{l}\text { Physico-geographical regions: morphology, } \\
\text { geology, soil cover, methods of land exploitation, } \\
\text { climatic conditions, elevation above sea level, } \\
\text { geographical coordinates, retention, river network } \\
\text { distribution and density }\end{array}$ & $\begin{array}{l}\text { Ecoregions: geographical position, water-parting } \\
\text { boundaries, height above sea level, dimensions } \\
\text { based on catchment area, geology }\end{array}$ \\
\hline RIVER VALLEY & $\begin{array}{l}\text { Parameters: width, ways of exploitation of } \\
\text { riparian zone and river valley, type and area of } \\
\text { exploited land }\end{array}$ & \multirow{3}{*}{$\begin{array}{l}\text { Hydromorphological elements supporting } \\
\text { biological elements: } \\
\text { a. hydrological regime: quantity and dynamics of } \\
\text { water flow, contact with groundwater aquifers } \\
\text { b. river continuity } \\
\text { c. morphological conditions: river depth and } \\
\text { width, bed-rock structure and composition, } \\
\text { structure of riparian zone } \\
\text { Chemical and physico-chemical elements: } \\
\text { a. general: thermal conditions, oxygen conditions, } \\
\text { salinity, acidification status, nutrient conditions } \\
\text { b. specific pollutions }\end{array}$} \\
\hline $\begin{array}{l}\text { MORPHOLOGY OF } \\
\text { THE RIVER CHANNEL }\end{array}$ & $\begin{array}{l}\text { Parameters: course, dikes, longitudinal section } \\
\text { and cross-section, morphology of slopes, scope } \\
\text { and methods of regulation, existing water objects } \\
\text { and technical reinforcements }\end{array}$ & \\
\hline $\begin{array}{l}\text { HYDROLOGY OF } \\
\text { THE RIVER AND } \\
\text { PHYSICO- CHEMICAL } \\
\text { PROPERTIES OF } \\
\text { WATER }\end{array}$ & $\begin{array}{l}\text { Hydrological elements: magnitude and variability } \\
\text { of discharges and water levels, width of water } \\
\text { surface } \\
\text { Physico-chemical elements: eutrophication, } \\
\text { mineral and organic pollution, sestone saprophity } \\
\text { ratio }\end{array}$ & \\
\hline $\begin{array}{l}\text { BIOCENOSIS (FLORA } \\
\text { AND FAUNA) }\end{array}$ & $\begin{array}{l}\text { Biological elements: } \\
\text { a. afforestation, vegetation of river channel slopes, } \\
\text { vegetation density and age, species of trees and } \\
\text { shrubs, shaded water ratio } \\
\text { b. aquatic plants: area, indicator species }\end{array}$ & $\begin{array}{l}\text { Biological reference conditions: } \\
\text { aquatic flora, benthic invertebrate fauna, fish } \\
\text { fauna }\end{array}$ \\
\hline
\end{tabular}

the system plays in the natural environment. An assessment of its key functions of a fluvial and ecological corridor, related to the assumptions of the concept of river continuum, is a basic problem in eco-hydrological studies (Gutry-Korycka 1999). It is particularly important in the case of rivers which drain protected areas or areas where human activity is limited that ensures their relatively high naturalness and spatial continuity. An interdisciplinary approach in studies on the structure and the state of functioning of the river system allows analysis of connections between its abiotic and biotic elements.

An assessment of the ecological state of the river system is based on different kinds of valorisation, as for example ecological (Karcz \& Sołowiej 1997), eco-morphological (Ilnicki \& Lewandowski 1997) and hydromorphological (Radecki-Pawlik 2006), which usually are carried out at two stages: identification of elements of the river system and proper classification of the system. River systems are most frequently characterized with the help of morpholog- ical, hydrological, physico-chemical and biological criteria examined at different levels, such as: basins and physico-geographical regions crossed by the river, river valley and river channel, flowing water and biocenosis (Table 1).

Groups of parameters presented in Table 1 are the most commonly used ones in eco-morphological valorisation of river systems. They are also components of thematic blocks defined in the Guidelines to the Water Framework Directive, referring to an assessment of the state and ecological potential of rivers. In each category, through characteristics and assessment of anthropogenic influence, a group of the river system users is specified and thresholds of natural resistance of the system to different kinds of influence are defined. As it can be seen in Table 1, there is a strong similarity between analysed information levels and a direct reference of basic instructions of the Water Framework Directive to main research problems of water ecosystems in the process of inventorying and classification of the river system properties. 
Table 2. Hydrographic and sozological databases - structure and progress to date

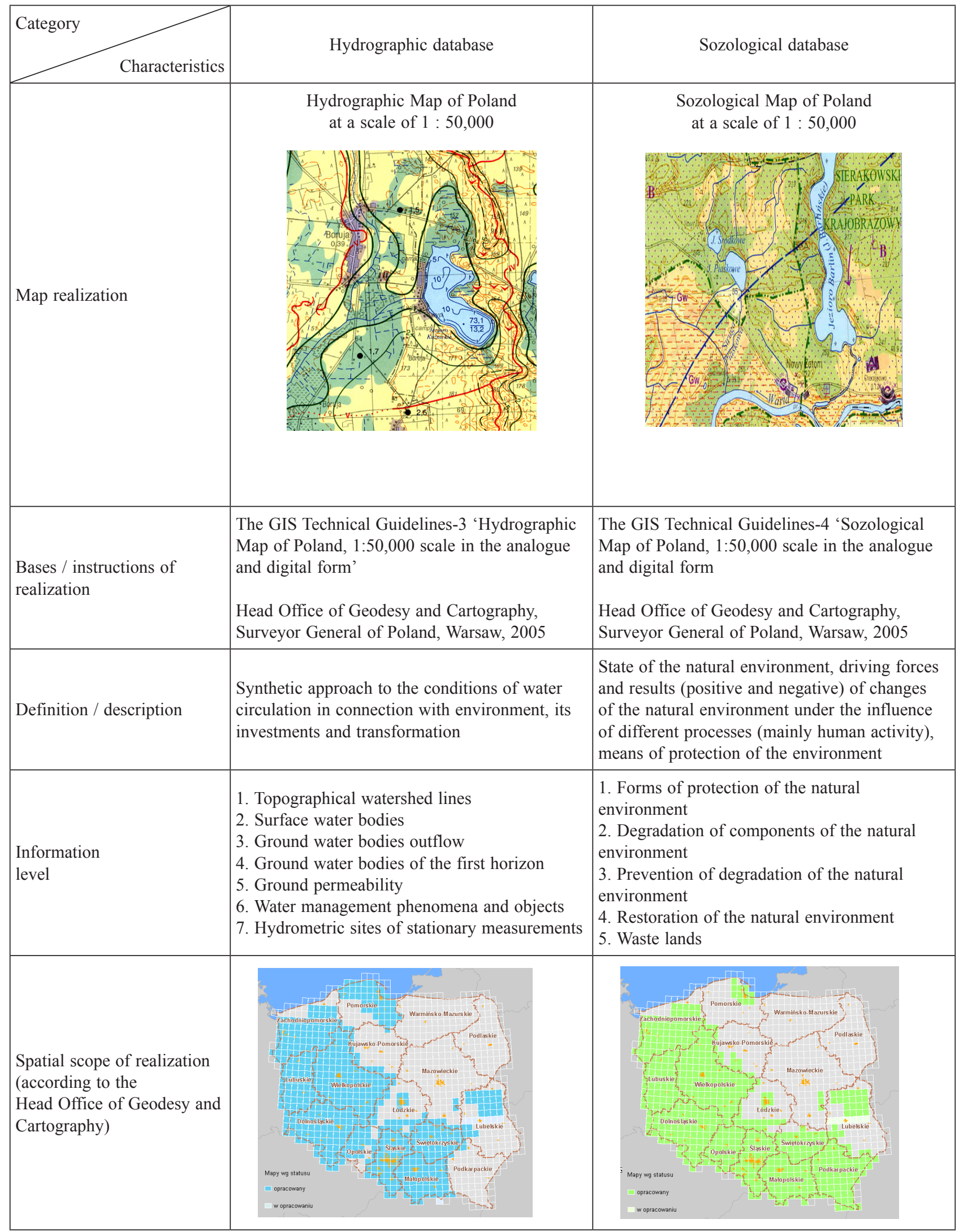


Depending on applied method of valorisation, at the preliminary stage, selected categories of parameters are attributed with a numerical modulus; its highest value reflects relatively natural state of an individual component of the river system that means slightly changed by human activity. Then, in the process of proper valorisation of the ecological state of streams, information obtained at the stage of identification and inventorying is converted into a form of summary coefficient, which is an arithmetic mean of summarized scores given to all parameters taken into account in the classification. At that stage of the analysis particularly important are series of source data used in valorisation and related to identification and the 'piece-by-piece' evaluation of individual elements of the river system. Ilnicki and Lewandowski (1997), who evaluated waterways of the Great Poland region, gave detailed description of the valorisation process.

\section{Hydrographic and sozological databases - their structure and progress to date}

In the process of valorisation of selected characteristics of the river systems both basic criteria (hydrological, morphological, physico-chemical, biological) and assumptions of main concepts (river continuum and ecological corridor, which define conditions of functioning of river ecosystems in the natural environment) are taken into account.

Two databases: hydrographic and sozological, which constitute a foundation for drawing serial thematic maps at a scale of 1:50,000 - the Hydrographic Map of Poland and the Sozological Map of Poland edited by the Head Office of Geodesy and Cartography, can illustrate the possible use of thematic databases in eco-hydrological studies on rivers (Table 2).

The above-mentioned databases are realized in reference to the standardized system of topographical references VMap L2 (Graf et al. 2005) and they satisfy the tendency to the two-form modelling of spatial data, namely as a digital map and a cartographic drawing. The GIS Technical Guidelines-3 (2005) and The GIS Technical Guidelines-4 (2005) provide instructions on technology of realization of databases as well as on principles of a proper implementation of spatial analyses and visualization of spatial data.

Usefulness of the two databases in eco-hydrological studies on river systems is determined by goals and thematic scope they realize. Information levels of the sozological database refer to the structure and the state of functioning of individual components of the natural environment and their transformations caused mainly by human activity and means of their protection (Table 2). While the hydrographic database provides information on water conditions in the examined area in relation to the natural environment, its development and transformation.
The presented databases and digital maps have a layered structure, which allows on the one hand analysing each layer separately and on the other hand compiling several layers. Application of the GIS technology in realization of the databases together with their spatial extent enables exchange of information with other topographic and thematic databases. However, information on the state of the water environment in a given situation, collected in the databases and projected on thematic maps, has to be permanently updated. This can be accomplished through regular hydrological and sozological mapping carried out in different seasons and different field conditions as well as through communication with databases originating from other systems of spatial information.

\section{Potential use of hydrographic and sozolog- ical databases in identification of character- istics of water systems}

Analysis of the thematic scope and properties of the hydrographic and sozological databases allows defining their possible use at different stages of eco-hydrological studies of river systems, particularly at the stage of identification and valorisation of the systems' characteristics important from the point of view of an assessment of their ecological state.

Information stored in the analysed thematic databases enables spatial localization of hydrographic units and objects. Therefore, identification of the river system characteristics and their parameterisation can be carried out - according to the assumptions of valorisation - at the catchment level or it can be limited to the river valley or the stream channel. Hydromorphological description which includes hydrological regime, river continuum and morphology of the main channel along with the degree of development and exploitation of the river valley is an inseparable part of classification of the ecological state of streams (Table 1). In relation to that group of elements these information levels were separated from the analysed databases (Table 3), which can be useful in evaluation of the spatial continuity of river valleys.

Data obtained from the information levels of hydrographic and sozological databases and analysed in relation to the criteria of valorisation of water ecosystems can be integrated into one coherent bank of source information on river systems. Created on its basis set of data contains in particular information on hydrological and morphological elements of streams and stream valleys as well as information on water management phenomena and objects which significantly modify the state of water ecosystems in a catchment.

In analysis of hydrological elements it is very important defining such properties as constant operation (func- 
Table 3. Hydrographic and sozological databases - selected thematic layers and their compilations applied in identification of parameters of river system

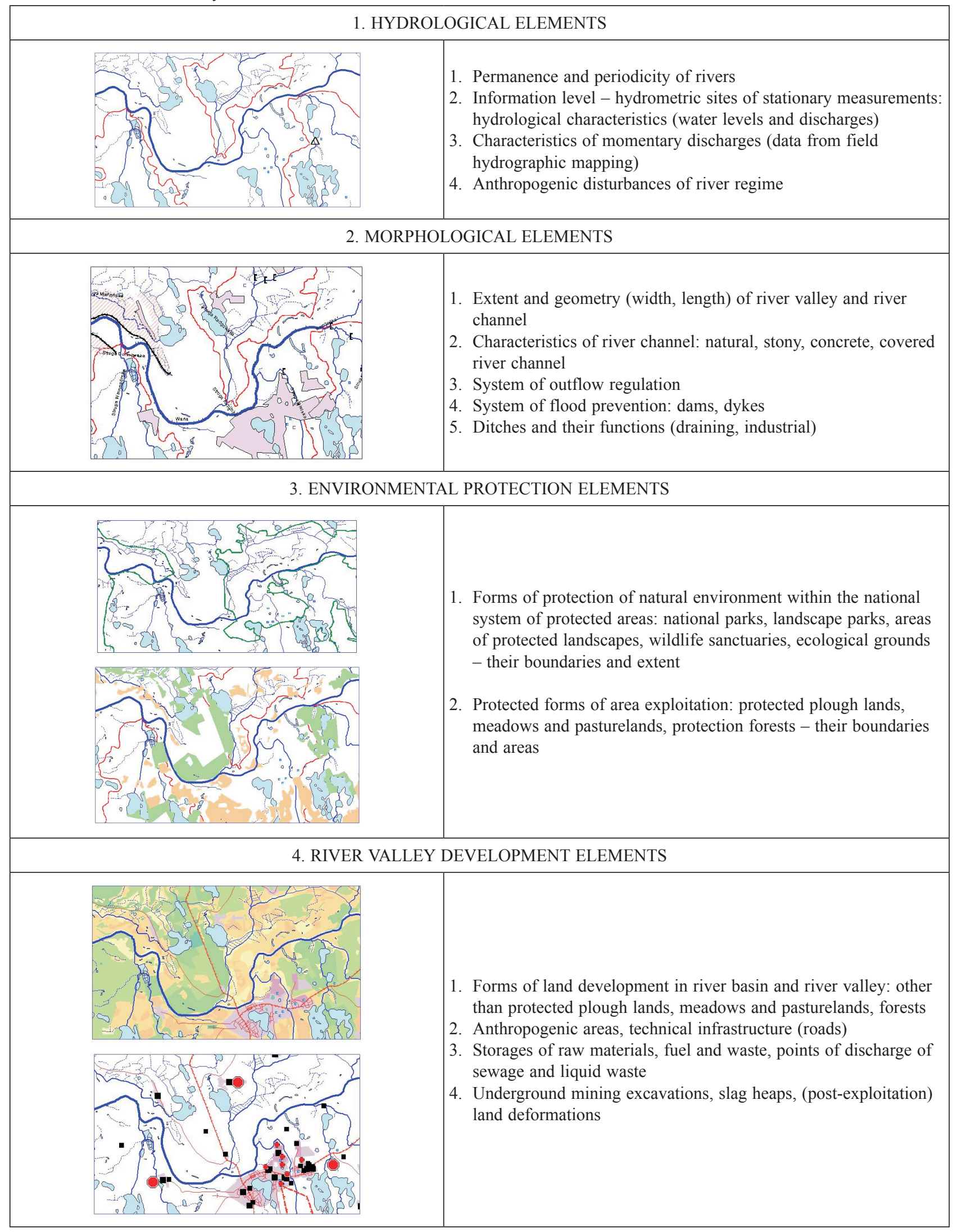


tioning) of streams and their hydrological characteristics - water stages and discharges. In this case it is helpful the "Hydrometric sites of stationary measurements" information level of the hydrographic database. Data provided by that level, supplemented with information on morphology and degree of transformation of river channel and river valley, enable an evaluation of outflow conditions and its anthropogenic disturbances. Particularly useful it is information on the type of the river channel (Table 3), outflow regulation and flood prevention systems, i.e. on elements significantly disturbing natural outflow.

Both hydrographic and sozological databases provide information on the degree of transformation of river channels due to hydrotechnical works. Analysis of such information allows distinguishing a category of artificial river sections, for example canals and ditches. In addition, it describes their functions and points out sections of river channel significantly changed by human activity, for example streams with concrete channel or with built-in rapids correction. According to the Guidelines to the Water Framework Directive, selected in that way parts of surface waters are attributed with so-called ecological potential, i.e. an ability to recover to the quasi-natural state.

The "Forms of protection of the natural environment" level of the sozological database, which is related to forms of protection of the natural environment recognized by the state system of protected areas (for example national parks, landscape parks) and also protected forms of land exploitation (such as protected plough lands, meadows, pasturelands and protection forests), constitutes a basis for analyses aiming to identify environmentally valuable (protected) sections of river valleys (Table 3 ).

The "Water management phenomena and object" hydrographic database and the "Degradation of components of the natural environment" sozological database are useful the elements of river valley development. It refers in particular to defining the degree of urbanization of the valley, location of municipal investments, infrastructure (roads, bridges) and hydrotechnical objects that elements reducing spatial continuity of river valleys, hence indicating the degree of the man-made changes (Table 3). That information can be supplemented with data on the quality and degree of water degradation, including type of pollution, origin and points of discharge of sewage, which significantly enhances information capacity of databases related to river systems.

\section{Conclusions}

This paper presents only few possible uses of hydrographic and sozological databases in eco-hydrological studies on river systems. Presented databases as independent set of information are not sufficient for evaluation of ecologi- cal state of surface waters. However, if they are integrated with other spatial databases, for example those related to biological and physico-chemical parameters of individual rivers, they can compose a very rich and updateable source of information, which can be used in identification and valorisation of properties of river ecosystems. Compilation of thematic layers of hydrographic and sozological databases presented in this paper, together with the possibility of their supplementation with data originating from various external sources, can constitute a basis for carrying out spatial analyses related to an assessment of the state and degree of transformation of the water environment. Information systems on rivers, created in that way, may be used in an evaluation of their properties, in an assessment of the river system vulnerability to human activity and also in forecasting potential changes in these systems. Moreover, results of analyses related to classification of the degree of naturalness (natural state) of streams and to the extent of transformations of river network are essential components of plans of water resources management and protection.

\section{References}

Adger W. N., 2006, Vulnerability. Global Environmental Change 16(3): 268-281.

Berry J. K. 2006, Map analysis. Procedures and applications in GIS modeling, BASIS Press (URL: http:// www. Innovativegis.com/basis/MapAnalysis/).

Bonham-Carter G. F., 1994, Geographic information systems for geoscientists: Modelling with GIS, Pergamon, Ottawa.

Brooks N., Adger W. N. \& Kelly P. M., 2005, The determinants of vulnerability and adaptive capacity at the national level and the implications for adaptation, Global Environmental Change 15: 151-163.

CODGiK GUGiK Centralny Ośrodek Dokumentacji Geodezyjnej i Kartograficznej Głównego Urzędu Geodezji i Kartografii [Main Documentation Centre of Geodesy and Cartography of the Head Office of Geodesy and Cartography, http://www.serwisy.codgik.gov.pl [accessed 11.05.2010].

DeMers M. N., 2005, Fundamentals of geographic information systems, Wiley, New York.

Dollar E. S. J., James C. S., Rogers K. H. \& Thoms M. C., 2007, A framework for interdisciplinary understanding of rivers as ecosystems, Geomorphology 89(1): 147162.

EEA, 2005, Guide to geographical data and maps, European Environment Agency - Technical report, URL: http:// www.eionet.eu.int/gis [accessed 11.05.2010].

European Commission, INSPIRE Geoportal, www.inspire-geoportal.eu [accessed 11.05.2010]. 
European Commission, INSPIRE Infrastructure for Spatial Information in the European Community, http://inspire. jrc.ec.europe.eu [accessed 11.05.2010].

GEO Group on Earth Observations, http:/www.earthobservations.org [accessed 11.05.2010].

GEOSS Global Earth Observation System of Systems, http://www.epa.gov/geoss/index.htm [accessed 11.05.2010].

GMES Global Monitoring for Environment and Security, http:/www.Esa.int/Observing-the-Earth/GMES [accessed 11.05.2010].

Gordon N. D., McMahon T. A. \& Finlayson B. L., 1992, Stream hydrology - an introduction for ecologists, Wiley, Brisbane.

GSDI Global Spatial Data Infrastructure Association, Association Information, http://www.gsdi.org [accessed 11.05.2010].

Graf R., 2009, Znaczenie bazy danych hydrograficznych w zakresie implementacji Ramowej Dyrektywy Wodnej [The significance of the hydrographic database in the area of implementation of the Water Framework Directive], [in:] A. T. Jankowski, D. Absalon, R. Machowski, M. Ruman (eds.), Przeobrażenia stosunków wodnych warunkach zmieniającego się środowiska [Changes of hydrographic conditions in conditions of the changing environment], Wyd. Uniw. Śl, Sosnowiec: 141-153.

Graf R., Kaniecki A. \& Żynda S., 2005, Rola i miejsce baz danych tematycznych GUGiK w krajowej infrastrukturze danych przestrzennych [The Role and Place of Thematic Databases GUGiK in the State Infrastructure of Spatial Data], Geodeta 10(125), Warszawa: 39-42.

Graf R. \& Olszewski R., 2006, Wykorzystanie bazy danych HYDRO dla potrzeb zarządzania zasobami wodnymi w sytuacjach kryzysowych [Use of the hydro database for the purposes of water resource management in critical situations], Roczniki Geomatyki 4(1): 85-95.

GUGiK Główny Urząd Geodezji i Kartografii [Head Office of Geodesy and Cartography], Systemy GIS [GIS Systems], http://gugik.gov.pl [accessed 11.05.2010].

GUGIK Główny Urząd Geodezji i Kartografii [Head Office of Geodesy and Cartography], Projecty GUGiK [GUGiK Projects], Geoportal, http://www.geoportal. gov.pl [accessed 11.05.2010].

Gutry-Korycka M., 1999, Zlewnia jako ekosystem dynamiczny [Catchment as a Dynamic Ecosystem], [in:] W. Chełmicki (ed.), Interdyscyplinarność w badaniach dorzecza (referaty wstępne), Materiały Ogólnopolskiej Konferencji Hydrologicznej, Kraków - Dobczyce [Interdisciplinarity in Basin Research (Preliminary Papers), Proceedings of the All-Polish Hydrological Conference, Kraków-Dobczyce], Kraków: 33-54.

Harper D. M., Zalewski M. \& Pacini N., 2008, Ecohydrology: Processes, Models and Case Studies: an Approach to the Sustainable Management of Water Resources, CABI, Wallingforg, Oxfordshire.

Huggenberger P., Hoehn E., Beschta R. \& Woessner W., 1998, Abiotic aspects of channels and floodplains in riparian ecology, Freshwater Biology 40(3): 407-425.

Ilnicki P. \& Lewandowski P., 1997, Ekomorfologiczna waloryzacja dróg wodnych Wielkopolski [Eco-morphological Valorisation of Waterways of Great Poland], Bogucki Wydawnictwo Naukowe, Poznań.

Janauer G. A., 2000, Ecohydrology: fusing concepts and scales, Ecological Engineering 16: 9-16.

Karcz G. \& Sołowiej D., 1997, Waloryzacja ekologiczna obszaru Zielonej Wstęgi Odra - Nysa w ramach projektu WWF Podstam (World Wildlife Fund For Nature) [Ecological Valorisation of the Green Belt Odra Nysa Area within the WWF Project Podstam (World Wildlife Fund For Nature)], [in:] S. Żynda (ed.), Kartografia w ochronie środowiska przyrodniczego i zagospodarowaniu przestrzennym [Cartography in Environmental Protection and Spatial Planning], XXIV Ogólnopolska Konferencja Kartograficzna, 13-15.11.1997 Poznań [The 24 $4^{\text {th }}$ All-European Cartographic Conference, 1315 November 1997 Poznań], Poznań: 349-352.

Kennard M. J., Mackay S. J., Pusey B. J., Olden J. D. \& Marsh D., 2010, Quantifying uncertainty in estimation of hydrologic metrics for ecohydrological studies, River Research and Applications 26(2): 137-156.

Longley R. A., Goodchild M. F. Maguire D. J. \& Rhind D. W., 2005, Geographical information systems: Principles, techniques, management and applications, Hoboken, Wiley, New, Jork.

Olszewski R., Graf R., Macias A., Kołodziej A. \& Berus T., 2010, Integracja baz danych tematycznych i referencyjnych w ramach tworzenia infrastruktury informacji przestrzennej w Polsce [Integration of thematic and reference databases within creation of the spatial information infrastructure in Poland], Roczniki Geomatyki 8(1): 89-98.

Olszewski R., Macias A., Graf R., Kołodziej A. \& Berus T., 2009, Transpozycja dyrektywy INSPIRE [The transposition of directive the INSPIRE], Geodeta 8(171): 31-34.

Radecki-Pawlik A., 2006, Podstawy hydrogeomorfologii cieków górskich dla biologów [Essentials of Hydrogeomorphology of Mountain Streams for Biologists], Belstudio, Inst. Nauk o Środ., Uniw. Jagielloński, Warszawa-Kraków.

Smit B. \& Wandel J., 2006, Adaptation, adaptive capacity and vulnerability, Global Environmental Change 16: 282-292.

Speth J. G., 2000, Unequal human impacts of environmental damage, [in:] A.K. Hegazy (ed.), Environment 2000 and Beyond, Horus for Computer and Printing, Cairo: 85-135. 
Store R. \& Jokimaki J., 2003, A GIS-based multi-scale approach to habitat suitability modeling, Ecological Modelling 169(1): 1-15.

The GIS Technical Guidelines-3 'Hydrographic Map of Poland, scale of 1:50,000, in the Analogue and Digital Form' [Wytyczne Techniczne GIS-3 „Mapa Hydrograficzna Polski, skala 1: 50 000, w formie analogowej i numerycznej"], 2005, Head Office of Geodesy and Cartography (GUGiK), Surveyor General of Poland,Warsaw.The GIS Technical Guidelines-4 'Sozological Map of Poland, scale of 1:50,000, in the Analogue and Digital Form' [Wytyczne Techniczne GIS-4 „Mapa Sozologiczna Polski, skala 1: 50 000, w formie analogowej i numerycznej'], 2005, Head Office of Geodesy and Cartography (GUGiK), Surveyor General of Poland, Warsaw.

Thoms M.C., 2003, Floodplain-river ecosystems: lateral connections and the implications of human interference, Geomorphology 56(3): 335-349.

Thoms M.C., Southwell M. \& McGinness H.M., 2005, Floodplain-river ecosystems: Fragmentation and water resources development, Geomorphology 71(2): 126138.

Thorp J.H., Thoms M.C. \& Delong M. D., 2010, The Riverine Ecosystem Synthesis: Toward Conceptual Cohesiveness in River Science, Elsevier, Academic Press, Boston.
UNDP, 2000, Human Development Report 2000, Oxford University Press, New York.

UNEP, 2002, Assessing Human Vulnerability due to Environmental Change: Concepts, Issues, Methods and Case Studies [htp://www.unep.org].

Wang F., 2006, Quantitative methods and applications in GIS, Taylor \& Francis, Boca Raton.

Water Framework Directive No. 2000/60/EC (Directive 2000/60/EC of the European Parliament and of the Council of 23 October 2000 Establishing a Framework for Community Action in the Field of Water Policy, 2000, Official Journal L 327, 22/12/2000.

Zalewski M., 2000, Ecohydrology - the scientific background to use ecosystem properties as management tools toward sustainability of water resources. Guest Editorial, Ecological Engineering 16: 1-8.

Zalewski M. (ed.), 2002, Guidelines for the Integrated Management of the Watershed - Phytotechnology and Ecohydrology, Chapter 9, FIETC Freshwater Management Series - Issue 5, United Nations Environmental Programme - Division of Technology, Industry and Economics - International Environmental Centre (UNEP-DTIE-IETC), UNESCO-IHP, Osaka \& Shiga Office, Japan: $157-167$. 
